\title{
Solution Conformation of Cyclo(D-Leu-L-Glu-L-His)2 and Its Relation with Highly Efficient and Enantiomer-Selective Catalysis
}

\author{
Masao TANIHARA and Yukio IMANISHI \\ Department of Polymer Chemistry, Kyoto University, \\ Honmachi, Yoshida, Sakyo-ku, Kyoto 606, Japan
}

(Received September 22, 1982)

\begin{abstract}
A cyclic hexapeptide cyclo(D-Leu-L-Glu-L-His) ${ }_{2}$ was synthesized and its conformational properties in $\left(\mathrm{CD}_{3}\right)_{2} \mathrm{SO}$ and $\mathrm{D}_{2} \mathrm{O}$ were investigated. The major conformation in $\left(\mathrm{CD}_{3}\right)_{2} \mathrm{SO}$ was asymmetric and possessed either a gramicidine-type $\beta$-turn structure or a random structure in one molecule. The major conformation in $\mathrm{D}_{2} \mathrm{O}$ was a $\mathrm{C}_{2}$-symmetric random structure. When $\mathrm{Cu}\left(\mathrm{ClO}_{4}\right)_{2}$ was added to an aqueous solution of cyclo(D-Leu-L-Glu-L-His) ${ }_{2}$ ( $\mathrm{pH} \mathrm{6.95}$, phosphate buffer), the major conformation of the latter changed from a random to a type-II $\beta$-turn structure. The cyclic hexapeptide/ $\mathrm{Cu}^{2+}$ molar ratio of the complex was unity, and $\mathrm{Cu}^{2+}$ was coordinated with Glu-COOH. Induced by copper-ion coordination the backbone plane, the Leu-isobutyl group, and the His-imidazolylmethyl group of cyclo(D-Leu-L-Glu-L-His) $)_{2}$ had the form of a hydrophobic pocket. The highly efficient hydrolysis of leucine or valine $p$-nitrophenyl ester hydrochloride by the cyclo(D-Leu-L-Glu-L-His) ${ }_{2}-\mathrm{Cu}^{2+}$ complex may be closely related to the binding of a substrate by the hydrophobic pocket. The weak enantiomer-selectivity may also be related to a streochemical fit of a bound substrate with the hydrophobic pocket.

KEY WORDS Solution Conformation / Cyclic Hexapeptide / NMR Spectroscopy / CD Spectroscopy / Cation Binding / Hydrophobic Pocket / Metal-Enzyme Model /
\end{abstract}

Our interest has been directed to the molecular design of an efficient and specific catalyst by controlling the stereochemistry involved in the intramolecular catalysis of multifunctional cyclic peptide catalysts toward a substrate which is bound by the catalyst due to hydrophobic or electrostatic interaction. In a series of investigations, we succeeded in carrying out the very fast and enantiomerselective hydrolysis of the $p$-nitrophenyl ester hydrochlorides of leucine [Leu-OPh $\left.\left(\mathrm{NO}_{2}\right) \cdot \mathrm{HCl}\right]$ and valine $\left[\mathrm{Val}-\mathrm{OPh}\left(\mathrm{NO}_{2}\right) \cdot \mathrm{HCl}\right]$ by a copper-ion complex of cyclo(D-Leu-L-Glu-L-His) ${ }_{2}$ consisting of hydrophobic (Leu), anionic (Glu) and nucleophilic (His) $\alpha$-amino acid residues. ${ }^{1}$

In cyclic compounds, the freedom of internal rotation is severely restricted and therefore the number of available conformations is reduced. This situation is very convenient for investigating on the conformation/reactivity relationship. Two examples have been reported in which a functionalized cyclic compound catalyzes an enantiomer-selective hydrolysis of active esters. Cram et al. ${ }^{2,3}$ observed a very high chiral recognition in the transacylation reaction of chiral amino ester salts including $\alpha$ amino acid ester hydrochlorides catalyzed by chiral crown ethers bearing thiol groups. Lehn and Sirlin ${ }^{4}$ reported a very high enantiomer-selectivity in the intramolecular thiolysis of dipeptide ester salts bound by 18 -crown- 6 derivatives having cystein methyl ester groups. However, in these chiral catalysts based on the crown compound, no experimental evidence has been obtained either with the conformation of a catalyst or with the orientation of functional groups in the substrate/catalyst complex, since the main chains of the cyclic compounds are very flexible.

The conformation of cyclic peptides is relatively rigid owing to amide bonds in the main chain, and can be analyzed by CD and NMR spectroscopy. The enantiomer-selective hydrolysis of Leu- 
$\mathrm{OPh}\left(\mathrm{NO}_{2}\right) \cdot \mathrm{HCl}$ and $\mathrm{Val}-\mathrm{OPh}\left(\mathrm{NO}_{2}\right) \cdot \mathrm{HCl}$ catalyzed by cyclo(D-Leu-L-Glu-L-His) ${ }_{2}$ was realized only when $\mathrm{Cu}\left(\mathrm{ClO}_{4}\right)_{2}$ was added to a phosphate-buffered aqueous solution. Under these conditions, it is resonable to assume the coordination of $\mathrm{Cu}^{2+}$ to Glu- $\mathrm{COOH}$ groups. In the present investigation mainly by CD and NMR spectroscopy, the solution conformation of cyclo(D-Leu-L-Glu-L-His) $)_{2}$ was investigated, and then the conformational change in the cyclic hexapeptide induced by complexation with metal ion was investigated. Finally, the relationship between the conformational properties of cyclo(D-Leu-L-Glu-L-His) ${ }_{2}$ and the highly efficient and enantiomer-selective catalysis is discussed.

\section{EXPERIMENTAL}

The synthesis and purification of cyclo(D-Leu-LGlu-L-His $)_{2}$ were reported in the preceding paper. ${ }^{1}$

The $270 \mathrm{MHz}^{1} \mathrm{H}$ NMR spectrum of cyclo(D-LeuL-Glu-L-His $)_{2}$ in $\left(\mathrm{CD}_{3}\right)_{2} \mathrm{SO}$ was measured using a Bruker WH 270 spectrometer, the internal standard being $\left(\mathrm{CH}_{3}\right)_{4} \mathrm{Si}$. The chemical shift, coupling constant, and isotope $(H / D)$ exchange rate of the amide protons were measured at $23^{\circ} \mathrm{C}$. The temperature dependence of the amide proton chemical shift was determined by changing the temperature in the range between $23^{\circ} \mathrm{C}$ and $103^{\circ} \mathrm{C} .{ }^{1} \mathrm{H}$ NMR spectrum was measured also in $\mathrm{D}_{2} \mathrm{O}\left(\mathrm{pD}\right.$ 6.23) and in $\mathrm{H}_{2} \mathrm{O}$ (pH ca. 4) at $23^{\circ} \mathrm{C}$, using $\mathrm{Me}_{3} \mathrm{Si}\left(\mathrm{CH}_{2}\right)_{3} \mathrm{SO}_{3} \mathrm{Na}$ as the internal standard.

The CD spectrum of an aqueous solution of cyclo(D-Leu-L-Glu-L-His) ${ }_{2}$ was measured with a JASCO J-20 spectropolarimeter at room temperature at pH $6.95\left(\mathrm{KH}_{2} \mathrm{PO}_{4} / \mathrm{NaOH}\right.$ buffer $)$.

Various metal and ammonium salts were added to the aqueous solution of cyclo(D-Leu-L-Glu-LHis) ${ }_{2}$ (pH 6.95) and the conformational change was followed by $\mathrm{CD}$ spectroscopy. The metal salts used were $\mathrm{Cu}\left(\mathrm{ClO}_{4}\right)_{2} \cdot 6 \mathrm{H}_{2} \mathrm{O}, \mathrm{CuCl}, \mathrm{MgCl}_{2} \cdot 6 \mathrm{H}_{2} \mathrm{O}$, $\mathrm{Zn}\left(\mathrm{ClO}_{4}\right)_{2} \cdot 6 \mathrm{H}_{2} \mathrm{O}, \quad \mathrm{FeCl}_{3} \cdot 6 \mathrm{H}_{2} \mathrm{O}, \quad \mathrm{AgClO}_{4}$ and $\mathrm{CaCl}_{2} \cdot 2 \mathrm{H}_{2} \mathrm{O}$. These were commercial and used without further purification. The ammonium salts were racemic $s-\mathrm{OctNH}_{2}$, DL-Val-OEt $\cdot \mathrm{HCl}$ and DLPhe-OMe $\cdot \mathrm{HCl}$. Racemic $s-\mathrm{OctNH}_{2}$ was commercial and used without further purification. $\alpha$-Amino acid ester hydrochlorides were synthesized by bubbling $\mathrm{HCl}$ through a suspension of the relevant $\alpha$ amino acid in ethanol or methanol and purified by recrystallization from $\mathrm{EtOH} / \mathrm{Et}_{2} \mathrm{O}$ mixture.

\section{RESULTS AND DISCUSSION}

\author{
Conformation of Cyclo(D-Leu-L-Glu-L-His $)_{2}$ in \\ $\left(\mathrm{CD}_{3}\right)_{2} \mathrm{SO}$
}

The $\mathrm{C}^{\alpha} \mathrm{H}$ region $(\delta=0-5 \mathrm{ppm})$ and the $\mathrm{NH}$ region $(\delta=7-9 \mathrm{ppm})$ of the $270 \mathrm{MHz}{ }^{1} \mathrm{H}$ NMR spectrum of cyclo(D-Leu-L-Glu-L-His) $)_{2}$ in $\left(\mathrm{CD}_{3}\right)_{2} \mathrm{SO}$ at $23^{\circ} \mathrm{C}$ are shown in Figures 1 and 2, respectively. Signal assignment was made according to Wüthrich ${ }^{5}$ and by the proton decoupling method. As seen in Figures 1 and 2, not only a major but also several minor conformations of cyclo(D-Leu-L-GluL-His $)_{2}$ occur in $\left(\mathrm{CD}_{3}\right)_{2} \mathrm{SO}$. Assignments were given to signals due to the major conformation, and signals to which no assignment was made were due to minor conformations. In Figure 2, in addition to the signals due to imidazolyl- $\mathrm{CH}$, six doublets of amide NH having nearly equal intensities are observed. Therefore, the major conformation of cyclo(D-Leu-L-Glu-L-His $)_{2}$ in $\left(\mathrm{CD}_{3}\right)_{2} \mathrm{SO}$ should be asymmetric. Besides these signals, the presence of more than 13 doublets having intensities of $1 / 2-$ $1 / 3$ as large as those above was confirmed by convolution difference spectra. Therefore, more than three kinds of minor conformations exist. In the expanded spectra of Figure 1, Leu- $\mathrm{CH}_{3}$ signals appearing in the $0.9 \mathrm{ppm}$ region were found to be quartet, triplet, and triplet looking down from a higher magnetic field. Among these three sets of signals, two should be assigned to the asymmetric major conformation and the other to a minor conformation. Signals appearing in the $4.5 \mathrm{ppm}$ region which are not well resolved are equally or more intense than those due to a major conformation such as $\mathrm{His}^{1}-\mathrm{C}^{\alpha} \mathrm{H}$ signals appearing in the $4.63 \mathrm{ppm}$ region. However, they did not change clearly by spin decoupling and therefore $\mathrm{C}^{\alpha} \mathrm{H}$ signals due to minor conformations must have been superposed on each other to result in an apparently increased intensity.

${ }^{1} \mathrm{H}$ NMR spectra were measured at $103^{\circ} \mathrm{C}$, too. $\mathrm{Glu}^{2}-\mathrm{NH}$ signals observed in the lowest magnetic field in Figure 2 were broadened so much that they almost disappeared with temperature rise, but a number of other signals due to either major or minor conformations was observed. However, Hisimidazolyl- $\mathrm{C}^{2} \mathrm{H}$ and His-imidazolyl- $\mathrm{C}^{4} \mathrm{H}$ signals converged from five $\left(23^{\circ} \mathrm{C}\right)$ to two $\left(103^{\circ} \mathrm{C}\right)$ and from three $\left(23^{\circ} \mathrm{C}\right)$ to one $\left(103^{\circ} \mathrm{C}\right)$, respectively, indicating magnetic equivalence at elevated temperatures in so 


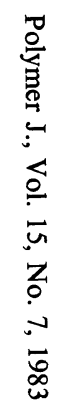

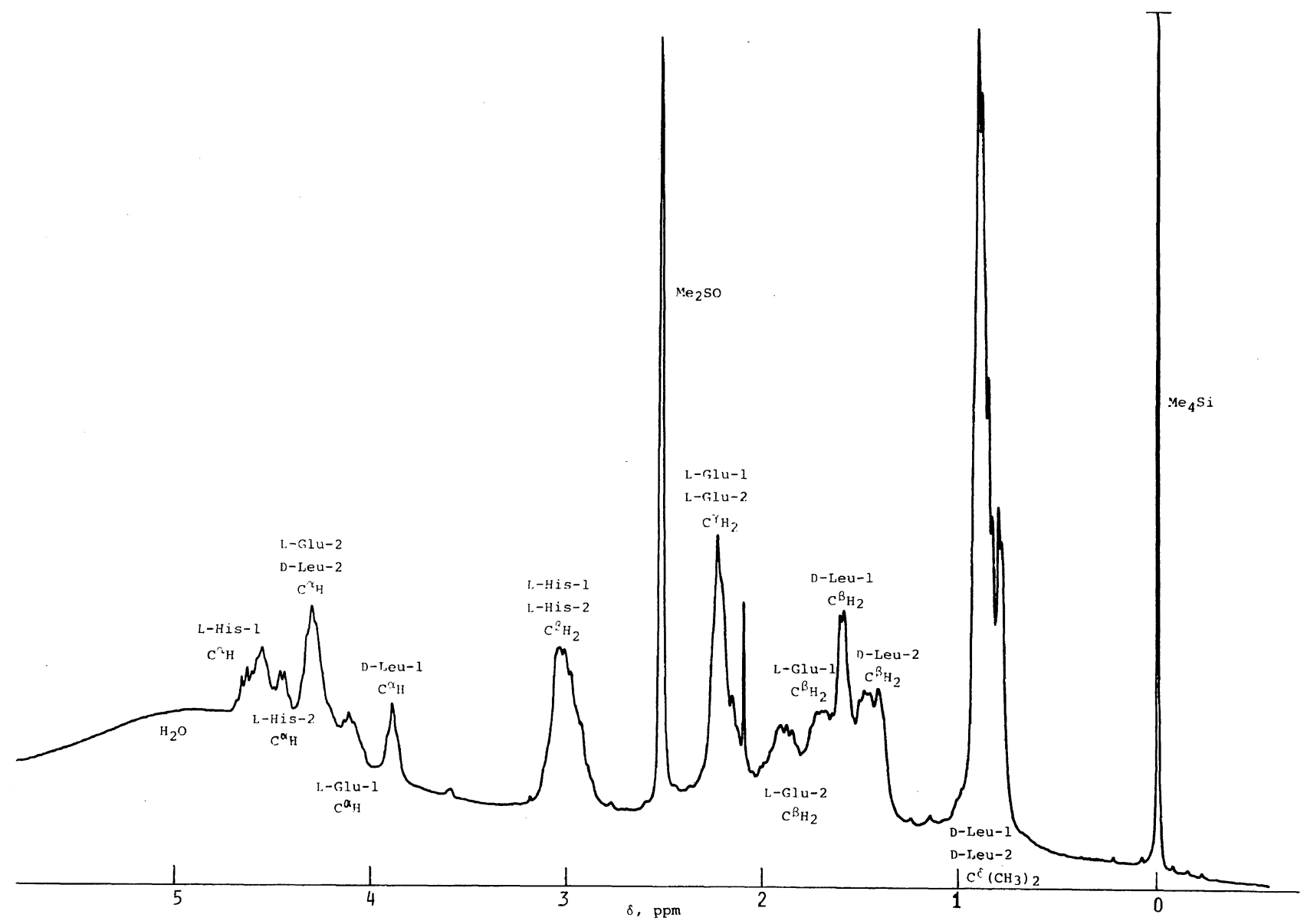




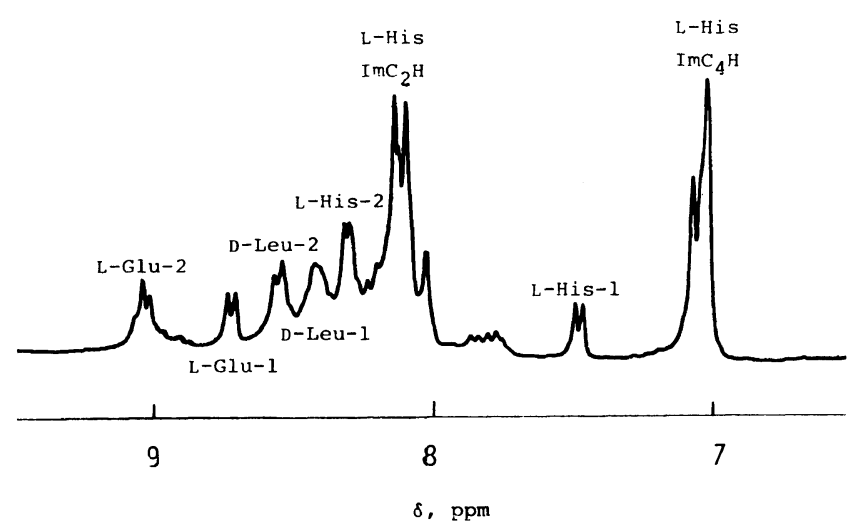

Figure 2. $\mathrm{NH}$ region of $270 \mathrm{MHz}{ }^{1} \mathrm{H}$ NMR spectrum of cyclo(D-Leu-L-Glu-L-His) in $\left(\mathrm{CD}_{3}\right)_{2} \mathrm{SO}$ at $25^{\circ} \mathrm{C}$.

Table I. ${ }^{1} \mathrm{H}$ NMR parameters of amide proton signals of cyclo(D-Leu $\left.{ }^{1}-\mathrm{L}-\mathrm{Glu}^{1}-\mathrm{L}-\mathrm{His}^{1}-\mathrm{D}-\mathrm{Leu}^{2}-\mathrm{L}-\mathrm{Glu}^{2}-\mathrm{L}-\mathrm{His}^{2}\right)$ in $\left(\mathrm{CD}_{3}\right)_{2} \mathrm{SO}$

\begin{tabular}{|c|c|c|c|c|c|}
\hline & $\delta^{\mathrm{a}}$ & $\mathrm{d} \delta / \mathrm{d} T \times 10^{3}$ & $K_{\mathrm{H}-\mathrm{D}}$ & $J_{\mathrm{H}-\mathrm{C}} \alpha_{-\mathrm{N}-\mathrm{H}}$ & $\theta_{\mathrm{H}-\mathrm{C}^{\alpha}} \alpha_{-\mathrm{N}-\mathrm{H}}$ \\
\hline & ppm & $\mathrm{ppm} \mathrm{deg}^{-1}$ & $\min ^{-1}$ & $\mathrm{~Hz}$ & $\operatorname{deg}$ \\
\hline L-Glu ${ }^{2}$ & 9.01 & -3.6 & 2.2 & 7.43 & 150 \\
\hline L-Glu ${ }^{1}$ & 8.71 & -5.0 & 0.12 & 7.43 & 150 \\
\hline D-Leu ${ }^{2}$ & 8.54 & -6.7 & 0.53 & 8.22 & 155 \\
\hline D-Leu ${ }^{1}$ & 8.37 & -3.0 & 0.26 & $<2$ & 90 \\
\hline $\mathrm{L}-\mathrm{His}^{2}$ & 8.30 & -7.5 & 0.08 & 6.26 & 140 \\
\hline L-His ${ }^{1}$ & 7.47 & 0.09 & 0.013 & 7.83 & 150 \\
\hline
\end{tabular}

a From $\left(\mathrm{CH}_{3}\right)_{4} \mathrm{Si}$.

b Calculated from $J_{\mathrm{H}-\mathrm{C}} \alpha_{-\mathrm{N}-\mathrm{H}}=7.9 \cos ^{2} \theta-1.55 \cos \theta-1.35 \sin ^{2} \theta$, ref 6 .

far as the side chains of His residues are concerned. On the other hand, triplet, quartet, and quartet signals were observed with Leu-C ${ }^{\delta} \mathrm{H}_{3}$ looking down from a higher magnetic field even at $103^{\circ} \mathrm{C}$. As in the case of the ${ }^{1} \mathrm{H}$ NMR spectrum at $23^{\circ} \mathrm{C}$, two sets of the three signals should be due to an asymmetric major conformation and the other to a minor conformation. This indicates that in the three conformations, the magnetic circumstances of the side chains of Leu residues are not equivalent even at $103^{\circ} \mathrm{C}$. However, the superposed signals in the $4.5 \mathrm{ppm}$ region due to minor conformations were observed in the ${ }^{1} \mathrm{H}$ NMR spectrum at $23^{\circ} \mathrm{C}$ and disappeared at $103^{\circ} \mathrm{C}$.

For the six amide NH signals observed in Figure 2 , the chemical shift from $\left(\mathrm{CH}_{3}\right)_{4} \mathrm{Si}$, the temperature dependence of chemical shift, the isotope exchange rate, the coupling constant with $\mathrm{C}^{\alpha} \mathrm{H}$, and the $\mathrm{H}-\mathrm{C}^{\alpha}$ -
$\mathrm{N}-\mathrm{H}$ dihedral angles calculated from the coupling constants using a Ramachandran equation ${ }^{6}$ were determined and are shown in Table I. Specifically, His ${ }^{1}-\mathrm{NH}$ signal shifted to a higher magnetic field by more than $0.5 \mathrm{ppm}$ compared to the other amide protons; its temperature dependence was positive and the isotope exchange rate much slower than that of the others. These findings indicate the features of intramolecularly hydrogen-bonded $\mathrm{His}^{1}$ $\mathrm{NH}$ in a $\beta$-turn structure. But the behavior of $\mathrm{His}^{2}$ $\mathrm{NH}$ was in great contrast to $\mathrm{His}^{1}-\mathrm{NH}$, indicating an asymmetric major conformation of the cyclic hexapeptide.

The coupling constants were determined on the basis of amide proton splittings. With the $\mathrm{Leu}^{1}$ residue, it was considered that $J_{\mathrm{H}-\mathrm{C}^{\alpha}-\mathrm{N}-\mathrm{H}}$ was extremely small and therefore $\theta$ was nearly $90^{\circ}$, since neither amide $\mathrm{NH}$ nor $\mathrm{C}^{\alpha} \mathrm{H}$ signals were well 
resolved and each decoupling caused only a small change in the signal of the counterpart. The decoupling of $\mathrm{Leu}^{1}-\mathrm{C}^{\beta} \mathrm{H}_{2}$ sharpened the $\mathrm{Leu}^{1}-\mathrm{C}^{\alpha} \mathrm{H}$ signal.

On the basis of the above experimental results, the major conformation of cyclo(D-Leu-L-Glu-L$\mathrm{His})_{2}$ in solution was considered to be that shown in Figure 3. According to Table I, His ${ }^{1}-\mathrm{NH}$ is considered to be intramolecularly hydrogen bonded. The tripeptide fragment $\mathrm{D}-\mathrm{Leu}^{1}-\mathrm{L}-\mathrm{Glu}^{1}-\mathrm{L}-\mathrm{His}^{1}$ represents a gramicidine S-type (type-I) $\beta$-turn structure $^{7}$ in Figure 3. In this type of conformation, the

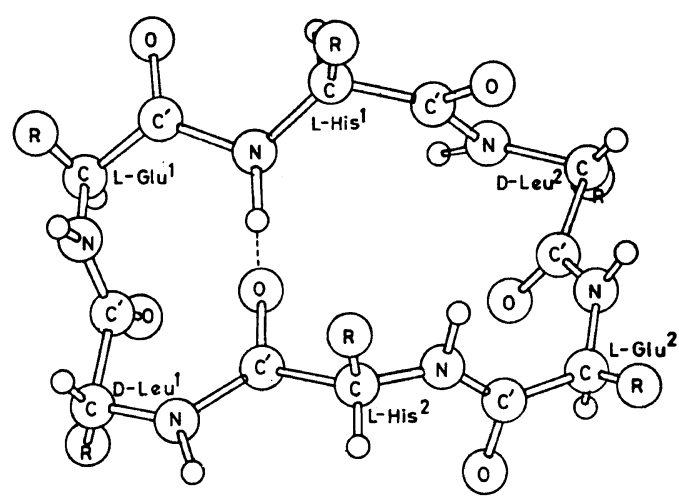

Figure 3. Proposed structure for the major conformer of cyclo(D-Leu-L-Glu-L-His) in $\left(\mathrm{CH}_{3}\right)_{2} \mathrm{SO}$. side chain of the $\mathrm{Leu}^{1}$ residue is situated in the $\beta$ turn, which is consistent with the results of ${ }^{1} \mathrm{H}$ NMR spectroscopy showing $\theta_{\mathrm{H}-\mathrm{C}^{\alpha}-\mathrm{N}-\mathrm{H}}$ of the $\mathrm{Leu}^{1}$ residue to be nearly $90^{\circ}$. The other tripeptide fragment $\mathrm{D}-\mathrm{Leu}^{2}-\mathrm{L}-\mathrm{Glu}^{2}-\mathrm{L}-\mathrm{His}^{2}$ takes a random conformation. In the ${ }^{1} \mathrm{H}$ NMR spectrum of the major conformation of the cyclic hexapeptide, two sets of signals almost equal in intensity were observed with amide protons belonging to the same kind of $\alpha$-amino acid residue. Therefore, the asymmetric conformation in which the $\beta$-turn and a random structures are present in one molecule (Figure 3) should be more plausible than a mixture of exactly equal amounts of a $\mathrm{C}_{2}$-symmetric conformer consisting of two $\beta$-turn structures and a $\mathrm{C}_{2}$-symmetric conformer having a completely random structure.

\section{Conformation of Cyclo(D-Leu-L-Glu-L-His $)_{2}$ in Aqueous Solution}

The $270 \mathrm{MHz}^{1} \mathrm{H}$ NMR spectrum of cyclo(D-Leu$\mathrm{L}-\mathrm{Glu}-\mathrm{L}-\mathrm{His})_{2}$ in $\mathrm{D}_{2} \mathrm{O}$ is shown in Figure 4 . The general pattern of the spectrum is quite similar to that in $\left(\mathrm{CD}_{3}\right)_{2} \mathrm{SO}$. Three kinds of Leu- $\mathrm{C}^{\delta} \mathrm{H}_{3}$ signals appear at $0.79 \mathrm{ppm}$ (quartet), $0.87 \mathrm{ppm}$ (quartet), and $0.94 \mathrm{ppm}$ (triplet) and are similar to those in $\left(\mathrm{CD}_{3}\right)_{2} \mathrm{SO}$. Eight signals of His-imidazolyl $\mathrm{C}^{2} \mathrm{H}$ appeared in the range of 8.14 to $8.51 \mathrm{ppm}$, and four

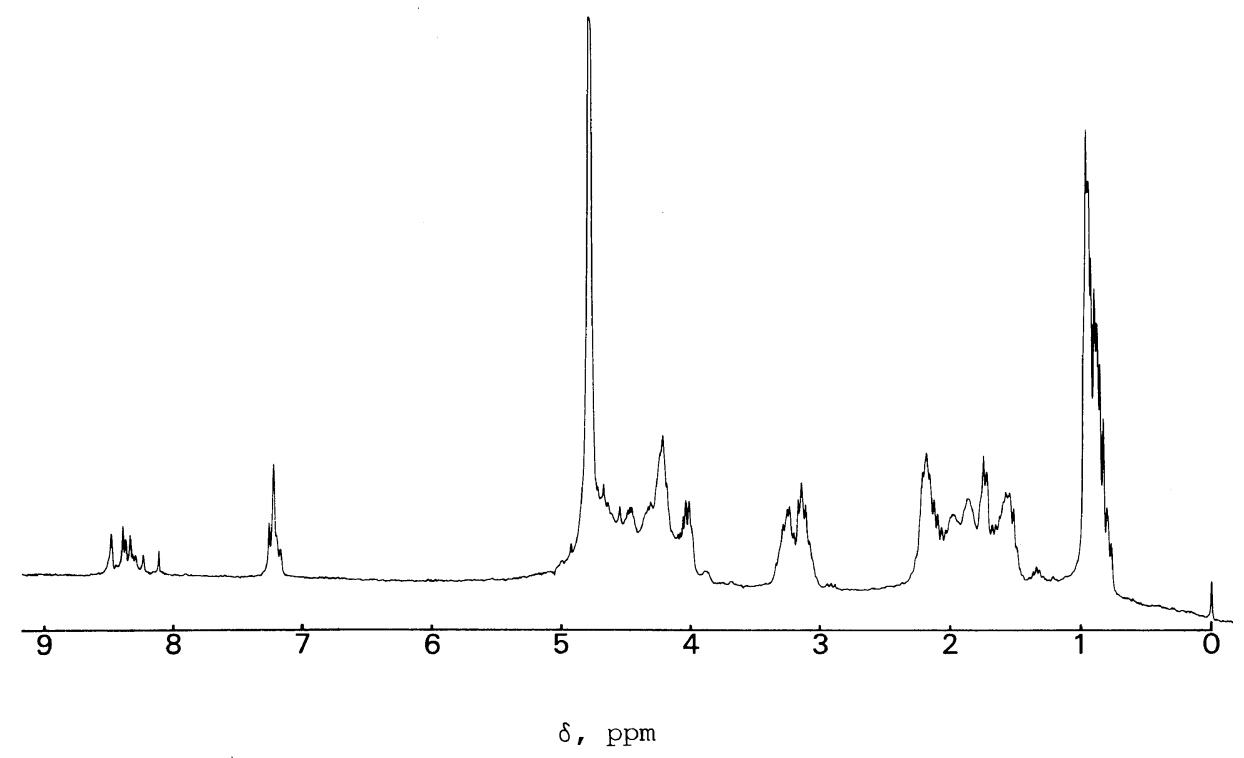

Figure 4. $270 \mathrm{MHz}^{1} \mathrm{H}$ NMR spectrum of cyclo(D-Leu-L-Glu-L-His) $)_{2}$ in $\mathrm{D}_{2} \mathrm{O}: \mathrm{pD}$ 6.24. 


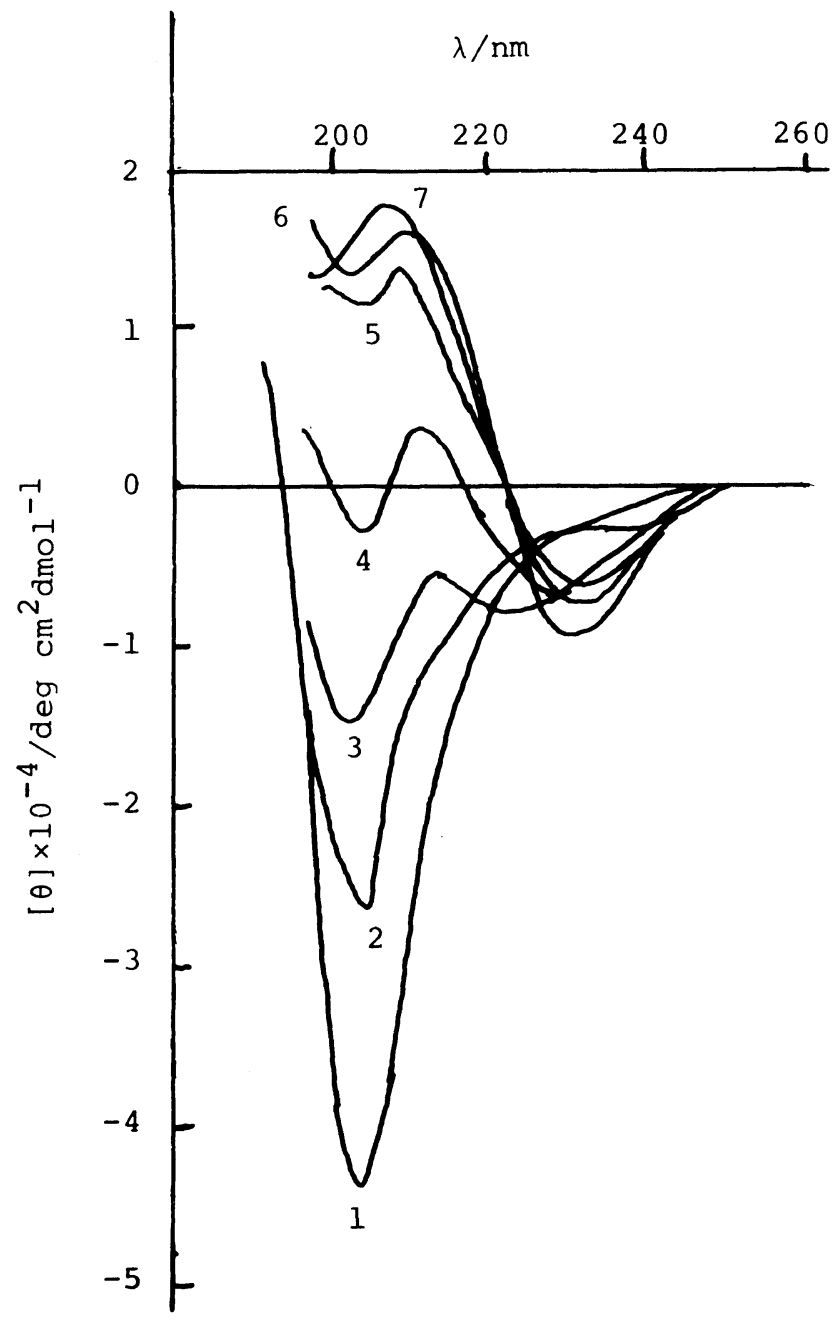

Figure 5. Change in $\mathrm{CD}$ spectrum of cyclo(D-Leu-L-Glu-L-His) $)_{2}$ induced by $\mathrm{Cu}\left(\mathrm{ClO}_{4}\right)_{2} \cdot 6 \mathrm{H}_{2} \mathrm{O}$ in aqueous solution: $\mathrm{pH}$ 6.95, [cyclo(D-Leu-L-Glu-L-His) $\left.)_{2}\right]=1.25 \times 10^{-4} \mathrm{~mol} \mathrm{dm}^{-3}:\left[\mathrm{Cu}\left(\mathrm{ClO}_{4}\right)_{2} \cdot 6 \mathrm{H}_{2} \mathrm{O}\right] \times 10^{4}$ $\mathrm{mol} \mathrm{dm}{ }^{-3}=0(1), 0.404(2), 0.810(3), 1.21(4), 1.82(5), 2.43(6), 5.67(7)$.

signals of His-imidazolyl $\mathrm{C}^{4} \mathrm{H}$ appeared in the range of 7.19 to $7.28 \mathrm{ppm}$. These experimental findings indicate that cyclo(D-Leu-L-Glu-L-His) ${ }_{2}$ in $\mathrm{D}_{2} \mathrm{O}$ consists of several conformers. Since three sets of amide NH signals having similar intensities appear in aqueous solution, a major conformation of cyclo(D-Leu-L-Glu-L-His) $)_{2}$ in aqueous solution should be $\mathrm{C}_{2}$-symmetric.

In Figure 5 , the $C D$ spectra of cyclo(D-Leu-LGlu-L-His) $)_{2}$ in aqueous solution are shown. Without any additives, a strong negative Cotton effect is observed at $203 \mathrm{~nm}$. This is commonly observable with polypeptides in a random conformation. ${ }^{8}$ Therefore, the $\mathrm{C}_{2}$-symmetric conformation of cyclo(D-Leu-L-Glu-L-His) ${ }_{2}$ concluded on the basis of ${ }^{1} \mathrm{H}$ NMR spectrum should be a random coil conformation. A weak negative shoulder of the Cotton effect was observed in the $230 \mathrm{~nm}$ peak of the $\mathrm{CD}$ spectrum as well. According to CD spectra of polypeptides having a $\beta$-turn structure, ${ }^{9}$ the negative shoulder should be ascribed to a gramicidine S-type $\beta$-turn structure. Therefore, as a minor conformation of cyclo(D-Leu-L-Glu-L-His) $)_{2}$ in aqueous solution, a gramicidine S-type (type-I) $\beta$ - 
turn structure is considered. This conclusion regarding the conformation of cyclo(D-Leu-L-Glu-L-His) in aqueous solution is consistent with the experimental observation that the NMR spectra of cyclo(D-Leu-L-Glu-L-His) in $\left(\mathrm{CD}_{3}\right)_{2} \mathrm{SO}$ and $\mathrm{D}_{2} \mathrm{O}$ were nearly of the same pattern.

\section{Conformational Change in Cyclo(D-Leu-L-Glu-L-} $\mathrm{His})_{2}$ in Aqueous Solution by the Addition of Metal-Ion Salts

The addition of $\mathrm{Cu}\left(\mathrm{ClO}_{4}\right)_{2} \cdot 6 \mathrm{H}_{2} \mathrm{O}$ to $1.25 \times 10^{-4}$ $\mathrm{mol} \mathrm{dm}{ }^{-3}$ aqueous solution of cyclo(D-Leu-L-Glu$\mathrm{L}-\mathrm{His})_{2}$ at $\mathrm{pH} 6.95\left(\mathrm{KH}_{2} \mathrm{PO}_{4} / \mathrm{NaOH}\right.$ buffer $)$ induced a serious change in the $\mathrm{CD}$ spectrum of the cyclic hexapeptide. In Figure 5, this change by the addition of $\mathrm{Cu}\left(\mathrm{ClO}_{4}\right)_{2} \cdot 6 \mathrm{H}_{2} \mathrm{O}$ up to a concentration of $5.67 \times 10^{-4} \mathrm{~mol} \mathrm{dm}^{-3}$ is shown. The CD spectrum of cyclo(D-Leu-L-Glu-L-His) ${ }_{2}$ obtained in the presence of 4.5 molar equivalence of $\mathrm{Cu}^{2+}$ is characteristic of the type-II $\beta$-turn structure. ${ }^{9}$ This indicates a conformational change in the cyclic hexapeptide from a random to a type-II $\beta$-turn structure.

A CD of $\mathrm{Cu}^{2+}$ chromophore was observed at $530 \mathrm{~nm}$ on adding $\mathrm{Cu}^{2+}$ to a phosphate-buffered aqueous solution of the cyclic hexapeptide; this was probably caused by the formation of the cyclic hexapeptide- $\mathrm{Cu}^{2+}$ complex and was very weak. The change in the $C D$ spectrum was not observed by the same procedure in the case of a citrate-buffered aqueous solution. These facts point to the chelation of $\mathrm{Cu}^{2+}$ by $\mathrm{Glu}-\mathrm{COOH}$ in the cyclic hexapeptide and a consequent conformational change in the cyclic hexapeptide backbone.

On the basis of Figure 5, the rotational strength in the $205 \mathrm{~nm}$ region was plotted against the concentration of $\mathrm{Cu}^{2+}$ added, giving the real line of Figure 6. In Figure 6, a point of inflection is observed, indicating the presence of complexes differing in composition. Assuming a 1:1 complex between the cyclic hexapeptide and $\mathrm{Cu}^{2+}$ and an equilibrium constant $4.04 \times 10^{-4} \mathrm{~mol} \mathrm{dm}^{-3}$, the rotational strength $/ \mathrm{Cu}^{2+}$ concentration relationship was calculated. The calculated curve is shown as a broken line in a good agreement with the real line. Therefore, the major complex should be a $1: 1$ complex between the cyclic hexapeptide and $\mathrm{Cu}^{2+}$. The cyclic hexapeptide in the $1: 1$ complex with copper ion takes a type-II $\beta$-turn structure in equilibrium with the free cyclic hexapeptide having a $\mathrm{C}_{2}$-symmetric random structure.

The change in the $\mathrm{CD}$ spectrum by the addition of metal-ion salts other than $\mathrm{Cu}\left(\mathrm{ClO}_{4}\right)_{2} \cdot 6 \mathrm{H}_{2} \mathrm{O}$ to

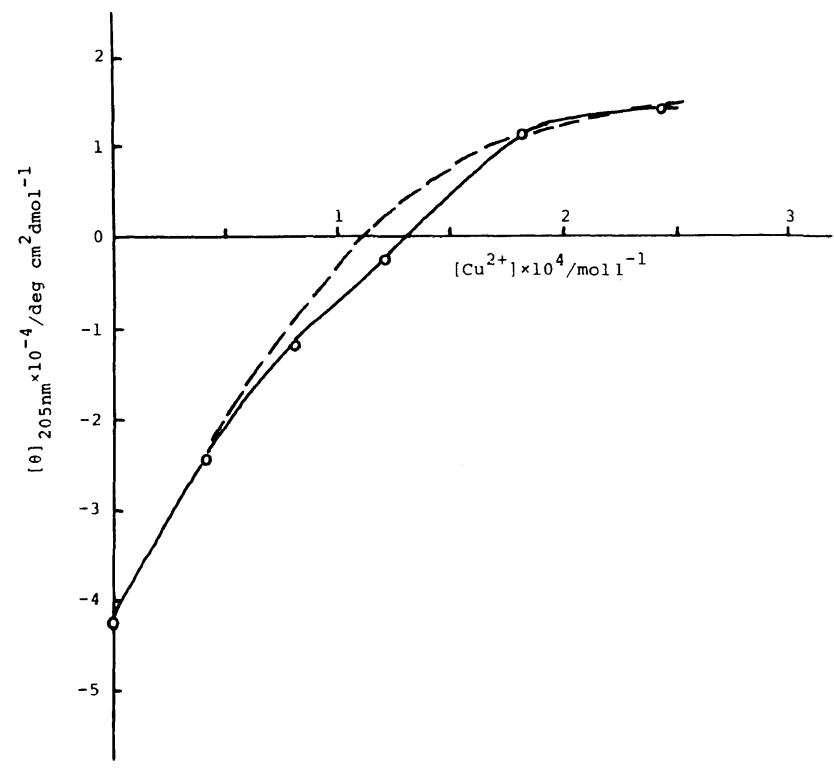

Figure 6. Molar elipticity at $205 \mathrm{~nm}$ of the CD spectrum of cyclo(D-Leu-L-Glu-L-His) $)_{2}$ versus concentration of copper perchlorate in aqueous solution: $\mathrm{pH} 6.95$; $\mathrm{O}$, observed value; ---, calculated value for $1: 1$ complex assuming an equilibrium constant $8 \times 10^{-4} \mathrm{~mol} \mathrm{dm}^{-3}$. 
$1.25 \times 10^{-4} \mathrm{~mol} \mathrm{dm}^{-3}$ aqueous solution of cyclo(DLeu-L-Glu-L-His $)_{2}$ at $\mathrm{pH} 6.95\left(\mathrm{KH}_{2} \mathrm{PO}_{4} / \mathrm{NaOH}\right.$ buffer) was investigated. $\mathrm{CuCl}$ induced a fairly large change in the spectrum. However, comparing the effects of $\mathrm{Cu}^{+}$and $\mathrm{Cu}^{2+}$ at $4.0 \times 10^{-4} \mathrm{~mol} \mathrm{dm}^{-3}$, the change by the latter was about twice that caused by the former. The addition of $2.96 \times 10^{-4} \mathrm{~mol}$ $\mathrm{dm}^{-3}$ of $\mathrm{AgClO}_{4}$ caused a small change, suggesting a conformational change to the type-II $\beta$-turn structure. The addition of other metal-ion salts such as $2.96 \times 10^{-4} \mathrm{~mol} \mathrm{dm}^{-3} \mathrm{FeCl}_{3} \cdot 6 \mathrm{H}_{2} \mathrm{O}, 2.46 \times 10^{-4}$ $\mathrm{mol} \mathrm{dm}{ }^{-3} \mathrm{MgCl}_{2} \cdot 6 \mathrm{H}_{2} \mathrm{O}, 2.72 \times 10^{-4} \mathrm{~mol} \mathrm{dm}^{-3}$ $\mathrm{CaCl}_{2} \cdot 2 \mathrm{H}_{2} \mathrm{O}$ and $2.47 \times 10^{-3} \mathrm{~mol} \mathrm{dm}^{-3}$ $\mathrm{Zn}\left(\mathrm{ClO}_{4}\right)_{2} \cdot 6 \mathrm{H}_{2} \mathrm{O}$, induced no remarkable change in the $\mathrm{CD}$ spectrum.

\section{Conformational Change in Cyclo(D-Leu-L-Glu-L-} $\mathrm{His})_{2}$ in Aqueous Solution by the Addition of Ammonium Salts

As models for substrates in the efficient and enantiomer-selective hydrolysis catalyzed by cyclo(DLeu-L-Glu-L-His) $)_{2}$, various ammonium salts were added to a $1.25 \times 10^{-4} \mathrm{~mol} \mathrm{dm}^{-3}$ aqueous solution of the cyclic hexapeptide at $\mathrm{pH} 6.95\left(\mathrm{KH}_{2} \mathrm{PO}_{4} /\right.$ $\mathrm{NaOH}$ buffer) and the change in the $\mathrm{CD}$ spectrum was followed. The addition of $5.08 \times 10^{-3} \mathrm{~mol} \mathrm{dm}^{-3}$ $s-\mathrm{OctNH}_{2}$ caused no change at all. The same was observed on adding $5.08 \times 10^{-3} \mathrm{~mol} \mathrm{\textrm {dm } ^ { - 3 }} s$ $\mathrm{OctNH}_{2}$ in the presence of $2.43 \times 10^{-4} \mathrm{~mol} \mathrm{dm}^{-3}$ $\mathrm{Cu}\left(\mathrm{ClO}_{4}\right)_{2} \cdot 6 \mathrm{H}_{2} \mathrm{O}$.

$7.16 \times 10^{-4} \mathrm{~mol} \mathrm{dm}{ }^{-3} \mathrm{DL}-\mathrm{Val}-\mathrm{OEt} \cdot \mathrm{HCl}$ did not bring about a serious change in the $\mathrm{CD}$ pattern of the cyclic hexapeptide. However, when $7.16 \times 10^{-4}$ $\mathrm{mol} \mathrm{dm} \mathrm{dL}^{-3} \mathrm{DL}-\mathrm{Val}-\mathrm{OEt} \cdot \mathrm{HCl}$ was added in the presence of $1.03 \times 10^{-3} \mathrm{~mol} \mathrm{dm}^{-3} \mathrm{Cu}\left(\mathrm{ClO}_{4}\right)_{2} \cdot 6 \mathrm{H}_{2} \mathrm{O}$, the pattern in the $200 \mathrm{~nm}$ region of cyclo(D-Leu-LGlu-L-His) ${ }_{2}$ changed to some extent as shown in Figure $7 \mathrm{a}$. The change of the pattern by DL-Phe$\mathrm{OMe} \cdot \mathrm{HCl}$ was more remarkable as shown in Figure 7b. The addition of $9.83 \times 10^{-4} \mathrm{~mol} \mathrm{dm}^{-3}$ DL-Phe$\mathrm{OMe} \cdot \mathrm{HCl}$ in the presence of $2.34 \times 10^{-4} \mathrm{~mol} \mathrm{dm}^{-3}$ $\mathrm{Cu}\left(\mathrm{ClO}_{4}\right)_{2} \cdot 6 \mathrm{H}_{2} \mathrm{O}$ induced a remarkable change in the $200 \mathrm{~nm}$ region.

On the other hand, the addition of $7.16 \times 10^{-4}$ $\mathrm{mol} \mathrm{dm} \mathrm{dm}^{-3} \mathrm{DL}-\mathrm{Val}-\mathrm{OEt} \cdot \mathrm{HCl}$ in the presence of $4.83 \times 10^{-4} \mathrm{~mol} \mathrm{dm}^{-3} \mathrm{Zn}\left(\mathrm{ClO}_{4}\right)_{2} \cdot 6 \mathrm{H}_{2} \mathrm{O}$ had no effect on the $\mathrm{CD}$ pattern of the cyclic hexapeptide. On consideration of these results, it may be concluded that a further conformational perturbation of cyclo(D-Leu-L-Glu-L-His) $)_{2}$ takes place by DL-Val$\mathrm{OEt} \cdot \mathrm{HCl}$ or $\mathrm{DL}-\mathrm{Phe}-\mathrm{OMe} \cdot \mathrm{HCl}$ when the cyclic hexapeptide takes the type-II $\beta$-turn structure by coordination of $\mathrm{Cu}^{2+}$.

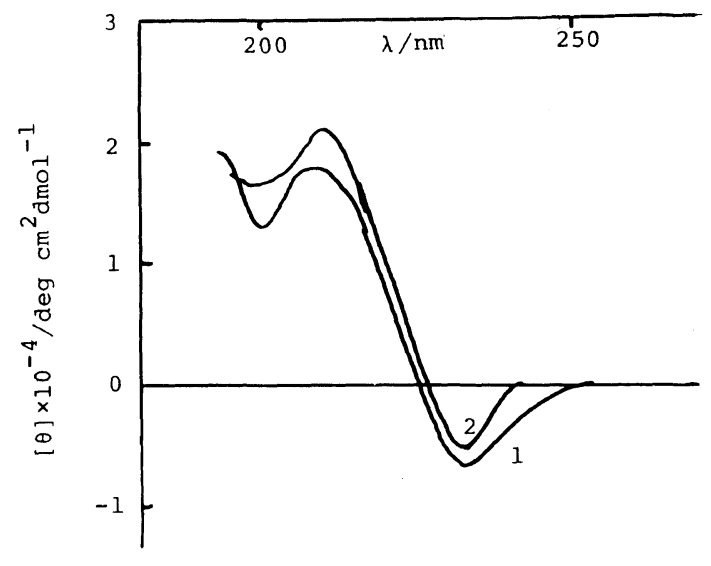

a

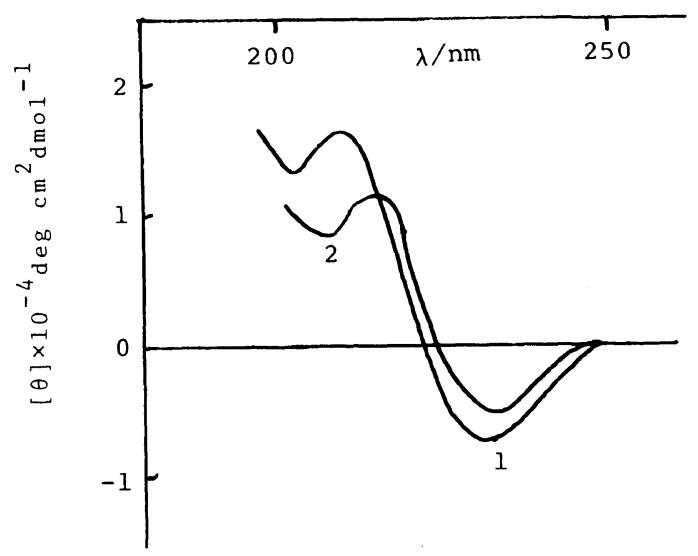

$\mathrm{b}$

Figure 7. CD spectra of cyclo(D-Leu-L-Glu-L-His) ${ }_{2}$ in aqueous solution: $\mathrm{pH} 6.95$, [cyclo(D-Leu-L-Glu-L$\left.\mathrm{His})_{2}\right]=1.25 \times 10^{-4} \mathrm{~mol} \mathrm{dm}{ }^{-3}: \quad$ a $, \quad\left[\mathrm{Cu}\left(\mathrm{ClO}_{4}\right)_{2}\right]=1.30 \times 10^{-3} \quad \mathrm{~mol} \mathrm{dm}^{-3}, \quad[\mathrm{DL}-\mathrm{Val}-\mathrm{OEt} \cdot \mathrm{HCl}]=0(1)$, $7.16 \times 10^{-4} \mathrm{~mol} \mathrm{dm}^{-3}(2): \mathrm{b},\left[\mathrm{Cu}\left(\mathrm{ClO}_{4}\right)_{2}\right]=2.43 \times 10^{-4} \mathrm{~mol} \mathrm{dm}^{-3},[\mathrm{DL}-\mathrm{Phe}-\mathrm{OMe} \cdot \mathrm{HCl}]=0(1), 9.84 \times 10^{-4}$ $\mathrm{mol} \mathrm{dm} \mathrm{m}^{-3}(2)$. 
Highly Efficient and Enantiomer-Selective Catalysis by Cyclo(D-Leu-L-Glu-L-His) ${ }_{2}$

Mainly from the CD spectra, cyclo(D-Leu-L-GluL-His) ${ }_{2}$ was found to form a $1: 1$ complex with $\mathrm{Cu}^{2+}$ in aqueous solution at $\mathrm{pH} 6.95$ in the absence of interfering ligands such as the citrate ion. $\mathrm{Cu}^{2+}$ coordinates with the side-chain carboxyl groups of the cyclic hexapeptide, inducing a conformational change from a random to type-II $\beta$-turn structure. Based on this, a molecular model of cyclo(D-Leu-LGlu-L-His) ${ }_{2}-\mathrm{Cu}^{2+}$ complex was constructed and is shown in Figure 8.

We synthesized a similar cyclic hexapeptide cyclo(Gly-L-Glu-Gly) ${ }_{2}$ and reported no evidence of a conformational change by the addition of $\mathrm{LiBr}$ or guanidine hydrochloride in $\left(\mathrm{CD}_{3}\right)_{2} \mathrm{SO} .{ }^{10}$ The reason for the different behavior of these two cyclic hexapeptides may be that the $\beta$-turn structure of cyclo(Gly-L-Glu-Gly) ${ }_{2}$ comes about without metal ions and is very stable and that the different solvents were used in the two experiments.

It should be remembered that a remarkable increase in catalytic activity and enantiomer-selective catalysis of cyclo(D-Leu-L-Glu-L-His) ${ }_{2}$ were possible only when the conformation changed from a random to the type-II $\beta$-turn structure through coordination of metal ions such as $\mathrm{Cu}^{2+}$. As can be seen from Figure 8, the side chains of the His and Leu residues are situated on the opposite sides of the Glu residue side chains and are complexed with $\mathrm{Cu}^{2+}$, with reference to the backbone plane of cyclo(D-Leu-L-Glu-L-His) ${ }_{2}$. In the preceding paper, ${ }^{1}$ it was shown that cyclo(D-Leu-L-Glu-L-His) strongly binds to a substrate by hydrophobic interaction and hydrolyzes it efficiently. It is thus conceivable that, according to the type of conformational change, the side chain isobutyl group of Leu residue and the side chain imidazolylmethyl group of the His residue are forced to come to the same side of the backbone plane, and that the backbone plane of the cyclic hexapeptide and the side chains of the Leu and His residues should constitute a hydrophobic pocket. This pocket facilitates the binding of the $\alpha$-amino acid ester hydrochloride more strongly and hydrolyzes it more rapidly. This idea of a hydrophobic pocket has been proposed for the enzyme catalysis ${ }^{11}$ and used to explain the rapid hydrolysis of $p$-nitrophenyl hexadecanoate by $S, S^{\prime}$-bis[cyclo(Gly-hemiCys-Gly-HisHex-Und)]. ${ }^{12}$ This idea can also be used to explain

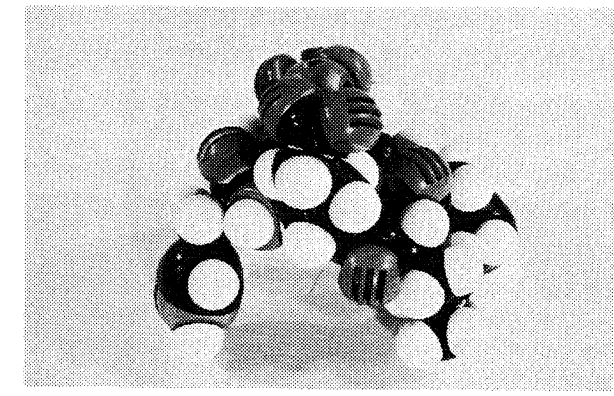

Figure 8. Side view of a space-filling molecular model of the cyclo(D-Leu-L-Glu-L-His) ${ }_{2}-\mathrm{Cu}^{2+}$ complex.

the highly efficient hydrolysis of $\alpha$-amino acid ester hydrochloride by the cyclo(D-Leu-L-Glu-L-His) ${ }_{2}-$ $\mathrm{Cu}^{2+}$ complex. Enantiomer recognition should be possible through the binding of a substrate to the hydrophobic pocket or subsequent intramolecular catalysis. Either of these may be the origin of the enantiomer-selective hydrolysis. $\mathrm{Cu}^{2+}$ plays an important role in the formation of chiral and hydrophobic pocket through coordination with the cyclic hexapeptide. In this sense, the cyclo(D-Leu-LGlu-L-His $)_{2}-\mathrm{Cu}^{2+}$ system is similar to a metal enzyme such as carboxypeptidase A.

During the process of substrate binding to the hydrophobic pocket, the conformation of the cyclic hexapeptide should change to some extent. This is supported by experiments using substrate-model compounds (Figure 7). Additional conformational change may have some bearing on the enantiomerselective catalysis of the cyclic hexapeptide. The enantiomer-selective hydrolysis of $\alpha$-amino acid ester hydrochlorides catalyzed by tripeptides having a cyclic dipeptide backbone has been reported, ${ }^{13}$ and has been interpreted in terms of conformational change in the tripeptide catalysts when the substrate is bound by hydrophobic interaction. ${ }^{14}$ However, the substrate model compounds employed in the present investigation could not induce a drastic change in the conformation of cyclo(D-Leu-L-GluL-His) ${ }_{2}$ and only caused a small perturbation in the large conformational change brought about by metal-ion salts. This may be one reason for the slight enantiomer-selectivity in the catalysis by the cyclo(D-Leu-L-Glu-L-His) ${ }_{2}-\mathrm{Cu}^{2+}$ complex compared to the remarkable increase in the rate by the copper-ion complexation with cyclo(D-Leu-L-GluL-His) ${ }_{2}$. 
Acknowledgment. The authors are deeply grateful to Professor T. Miyazawa of the University of Tokyo for permitting us to use the Bruker WH270 spectrometer and his helpful comments.

\section{REFERENCES}

1. M. Tanihara and Y. Imanishi, Polym. J., 15, 499 (1983)

2. Y. Chao and D. J. Cram, J. Am. Chem. Soc., 98, 1015 (1976).

3. Y. Chao, G. R. Weisman, G. D. Y. Sogah, and D. J. Cram, J. Am. Chem. Soc., 101, 4948 (1979).

4. J.-M. Lehn and C. Sirlin, J. Chem. Soc., Chem. Commun., 949 (1978).

5. K. Wüthrich, "NMR in Biological Research: Peptides and Proteins," North Halland, Amsterdam, 1976, p 51.
6. G. M. Ramachandran, R. Chandrasekaran, and K. D. Kopple, Biopolymers, 10, 2113 (1971).

7. C. A. Venkatachalam, Biopolymers, 6, 1425 (1968).

8. E. R. Blout, "Fundamental Aspects and Recent Developments in Optical Rotatory Dispersion and Circular Dichroism," F. Ciardelli and P. Salvadori, Ed., Heyden, London, 1973, pp 352-372.

9. C. A. Bush, S. K. Sarkar, and K. D. Kopple, Biopolymers, 17, 4951 (1978).

10. T. Sugihara, Y. Imanishi, T. Higashimura, and Y. Shimonishi, J. Org. Chem., 41, 2584 (1976).

11. T. A. Steitz, R. Henderson, and D. M. Blow, J. Mol. Biol., 46, 337 (1969).

12. Y. Murakami, A. Nakano, K. Matsumoto, and K. Iwamoto, Bull. Chem. Soc. Jpn., 51, 2690 (1978).

13. M. Tanihara, Y. Kikuchi, and Y. Imanishi, Int. J. Biol. Macromol., 4, 297 (1982).

14. Y. Kikuchi, M. Tanihara, and Y. Imanishi, Int. J. Biol. Macromol., 4, 305 (1982). 